gation and pracijcal skill in chemical manufacturing, gratifying though it be as a splendid achicvement of applied chemistry, is a sad trial to many thousands of Indian ryets and their British masters; and this is merely the foretaste of what will inevitably happen in many other cases. What is food for one is poison for another.

Perhaps the very greatest problem of applied chemistry is the direct production of feeding-stuffs for man and beast. The synthesis of alimentary substances from inorganic matter has, up to this moment, not been even remotely achieved, nor can we at present so much as guess the direction in which this might be done, whilst, as for the production of food from sawdust and other waste organic substances, we are in no better case. But even here the word " impossible" should not be pronounced. In a more modest form, at all events, chemistry has found magnificent scope in that quarter, viz. in the extraction of alimentary substances from new sources and in the increase of production from old ones. The colossal industry of beetroot sugar is an instance of the former, whilst asricultural chemistry, as a whole, works in the latter direction.

\section{UNIVERSITY AND EDUCATIONAL}

\section{INTELLIGENCE.}

Courses of lectures, and arrangements for informal instruction, have been arranged by the Oxford University Committee for Anthropology for the coming Easter term. There will be lectures and other instruction in general anthropology, physical anthropology, psychology, geographical distribution, prehistoric archæology, technology, sociology (religion, law, custom, \&c.), philology, and other subjects of interest to students of anthropology.

THE sum of $6 \mathrm{rool}$. has been subscribed by alumni of Harvard University to establish a Shaler memorial fund in commemoration of the long services of Prof. N. S. Shaler and of the great affection in which he was held by his many students and friends. It is proposed to place a memorial tablet in the geological section of the University museum, or some other suitable place, and to use the income of the balance for the benefit of the division of geology, in support of original research and in the publication of the results of research.

ON Tuesday, April 23, the Prince and Princess of Wales visited Glasgow and opened the new buildings at the University. These buildings were erected by Principal Story's university fund, which was largely raised by the efforts of the late Principal. They form an important addition to the laboratory and lecture-room equipment of the University. They consist of two large detached institutes to the west of the main building; one provides accommodation for the departments of physiology, materia medica, forensic medicine, and the other for the department of natural philosophy. The cost of the buildings has been defrayed by subscriptions to the amount of $40,000 l$. from the citizens of Glasgow and a grant of $40,00 \%$. from the Carnegie trustees. A special honorary graduation was held on the same day, at which the honorary degree of ILL.D. was conferred on the Prince and Princess of Wales, the Lord Provost of Glasgow (Mr. Wm. Bilsland), the Duchess of Montrose, the Chancellor of the Exchequer, who is also Rector of the University, Right Hon. Geo. Wyndham, a former Rector, Mr. Ure the SolicitorGeneral for Scotland, Sir George Watt, Sir W. R. Copland, Miss Galloway, Prof. Fmile Boutroux, Prof. Norman Collie, Prof. J. H. Poincaré, Mr. Sidney Lee, Mr. D. S. MacColl, Mr. Jas. A. Reid, Mr. N. Dunlop, Prof. J. G. McKendrick, Prof. G. G. Ramsay, Prof. A. M. Stuart, and Principal Donald Macalister.

ON Saturday last, April 20, the Borough Polytechnic Institute was open for the annual inspection and display of students' work. To judge from the crowds which thronged through the building during the evening, those who live in the neighbourhood must take a great interest in this educational centre. In the chemical laboratory there was an exhibition of electrochemical apparatus, and one saw the rapid deposition of metals by means of rotating electrodes. Apparatus for measuring the absorption taking place in reduction and oxidation methods was also shown working. In the general laboratory various chemical operations were in progress, such as fractionation, steam distillation, and the like. The general public who crowded the laboratories did not, of course, understand much, but they realised that what was to them mystical chemistry might be interesting, and perhaps a few of them will become students. The recently equipped electrotechnical department, which is in the engine-room, caused a good deal of interest. Many of the fittings have been put up by the students, who also helped to build up the experimental dynamo. The engineering department is becoming very complete, and students can now carry out tests upon quite a large scale. The latest addition here is a Delaval 5 horse-power steam-turbine engine coupled on to a dynamo. Some of the metal work and wood work executed by the students was of a very creditable character, the hammered copper work being especially interesting. A noteworthy exhibit was a vernier with micrometer screw which had been entirely madescale and all-by a lad sixteen years of age in the technical day school. The average person who passed through the institute on Saturday night would probably be most interested in the bakery and confectionery department or in the book-binding or shoe-making. All these, of course, are of great importance, and much good work is being done, but it should not be forgotten that on the scientific side, which tends above all things to the nation's advancement, good work is being done with a rather difficult material and a small staff, the chemistry department being one of the very few in Great Britain which publishes research work.

THE question of education in relation to the British Empire was considered at a meeting held in the Guildhall, London, on 'Tuesday, under the presidency of the Lord Mayor. The following resolutions were unanimously adopted:-(1) That in the opinion of this meeting of citizens of London and others, the education of the people of Great Britain on the subject of the Empire is deplorably backward, and that as an illustration of this fact it may be pointed out that no official map or text-book in regard to the Empire is available for teachers and the public; that in the opinion of this meeting the teaching of Empire subjects with the aid of official maps and text-books should be obligatory in all elementary and secondary schools in Great Britain, and that the Government be requested to lend official assistance in the preparation of such maps and text-books, and to sanction the permanent display of Empire maps in all schools, post-offices, and public buildings (moved by the Duke of Somerset and seconded by Dr. Parkin). (2) That a public subscription for the purpose of Empire education be inaugurated, and that the aid of the London and provincial Press and of all societies and associations, without regard to party politics, be invoked to collect funds for the purpose; that copies of these resolutions be sent to the Government, all lieutenants of counties, lord mayors, and mayors throughout the country, inviting them to call public meetings and submit thereto similar resolutions, and appeal for subscriptions to the fund (moved by Lord Milner and seconded by Mr. Dsakin). (3) That the fund be called the "Empire Education Fund," and that the first trustees shall be the Right Hon. Sir W. Treloar, Lord Mayor, his Grace the Duke of Somerset, the Right Hon. Viscount Milner, P.C., G.C.B., G.C.M.G., the Right Hon. Sir Rowland Blennerhassett, Bart., P.C., and Mr. Allen H. P. Stoneham (moved by Lord Strathcona and seconded by Lord Ranfurly).

A conference on the teaching of hygiene and temperance in the universities and schools of the British Empire was held in London on Tuesday. Lord Strathcona presided at the morning session and Sir John Gorst occupied the chair at the afternoon meeting. From the papers read it is clear that in several of our colonies and in some foreign countries much more attention is given to instruction in the laws of health than has yet been granted to it in this country. The chief object of the conference was to give prominence to this fact and to urge upon our educational authorities the importance of remedying the defect. Sir Victor Horsley, F.R.S., in an address on the method of introducing hygiene and temperance into secondary schools and universities, susgested that an 
essential reform within the Board of Education is that there shall be such advice given to the Minister of Education as will enable him to grasp the principles of scientific education. It is the business of the State to see that the code and curriculum of education are arranged on a scientific and common-sense basis, and this will necessarily include the hygiene of common life and instruction in temperance. Sir Victor Horsley contended that we shall not make any headway unless we have expert advice at headquarters. It is clear that the whole system of education requires revision from a medico-scientific standpoint. The following resolutions were unanimously adopted:(I) "That this conference has heard with great satisfaction that instruction in hygiene and temperance is systematically given in the elementary schools of the colonies of the Empire, and that there is strong evidence of the value of this teaching. While cordially acknowledging what has been already accomplished in the United Kingdom by certain educational bodies, this conference urges upon all local authorities the necessity of providing that the teaching of hysiene and temperance shall form an essential part of the whole curriculum of education of all children." (2) "This conference is of opinion that to meet adequately the responsibilities of the State towards school children, it is essential that a medical department should be instituted in the Board of Education.'

\section{SOCIETIES AND ACADEMIES.} LONDON.

Royal Society, February 7.-." On the Combining Properties of the Opsonin of an Immune Serum." By Prof. Robert Muir and W. B. M. Martin. Communicated by Dr. C. J. Martin, F.R.S.

(1) The thermolabile opsonin of a normal serum and the thermostable opsonin of an immune serum are two distinct classes of substances. In addition to differing markedly as regards their resistance to heat, they differ in their combining relationships.

(2) The thermostable opsonin of the anti-serum investigated is a true anti-substance, and possesses the comparatively specific characters of anti-substances in general; it is left undetermined whether it has the constitution of an agglutinin or of an immune body, though certain facts point in favour of the former.

(3) Emulsions of other organisms other than the organism used in immunisation (Staphylococcus aureus) do not absorb the immune opsonin; on the other hand, they absorb large amounts of the normal complement-like opsonin.

(4) Powerful complement-absorbers-red corpuscles or hacteria treated with immune body or serum precipitatehave no effect on the thermostable immune opsonin, whereas they remove almost completely the labile opsonin of the normal and the immune serum alike.

Faraday Society, March 19.--Dr. T. Martin Lnwry in the chair.-The potential of hydrogen liberated from metallic surfaces: H. Nutton and H. D. Law. The paper is chiefly concerned with the chemical reducing power of hydrogen when liberated from the surface of various metallic electrodes, and also the retarding action caused by the presence of small quantities of metallic salts. The metals are arranged in the following order:mercury, lead, cadmium, tin, silver, bismuth, gold, nickel, platinum (black), the first-mentioned metal being the most capable of bringing about the reduction of a compound not readily attacked; platinised platinum, on the other hand, possesses this property in the lowest degree. Zinc as a reducer behaves in a very irregular manner; both copper and platinum (black) show a remarkable activity in the reduction of aromatic aldehydes, and iron and aluminium are variable. It was hoped by a careful study of the electrode potentials that it might be possible to differentiate between the purely chemical changes and those which were due to physical causes.-Electrode potentials in liquid ammonia: N. T. M. Wilsmore and F. M. G. Johnson. The measurements of electrode potentials in liquid ammonia were undertaken with a view to the determination of the free energy of formation of a series of metallic salts, and thereby to compare the relative affinities of the corresponding metallic elements under conditions differing as much as possible from those obtaining in the case of measurements in aqueous salutions. To this end the electrode potentials of the metals against solutions of their salts of known strength were measured against a standard electrode (cadmium in a saturated solution of cadmium nitrate). The results are given in the paper in tabular form.--The impedance of solutes in solvents as manifested by osmotic pressure: J. G. A. Rhodin. 'The author's object is to substitute for the thecry of van 't Hoff, the main objection to which, in his opinion, is the direction of pressure, a theory which regards the solvent-and not the solute-as the source of the energy manifested in osmotic-pressure experiments.The electrolytic deposition of zinc, using rotating electrodes, part ii.: Dr. T. Slater Price. The effect of the addition of various electrolytes on the electrolytic deposition of zinc, using a rotating kathode and the apparatus described in the previous paper, has been investigated. In all the experiments the kathode was silvered before the zinc was deposited. Excellent results were obtained, using 2 grams of sodium sulphate and I gram of sodium acetate for each gram of crystallised zinc sulphate, the addition of free acetic acid being unnecessary. The number of revolutions per minute of the kathode was $600-700$, and the time of deposition was fourteen minutes.

Linnean Society, March 2r.--Prnf. W. A. Herdman, F.R.S., president, in the chair.-The origin of Angiosperms: E. A. Newell Arber and John Parkin. In attempting to trace the ancestry of this group, the authors commence by a survey of living Angiosperms with a view to determine which among them present primitive features, and also with the hope of arriving at some hypothesis as to the type of fructification possessed by the earliest members of the group. They dissent emphatically from the view generally held, and especially advocated by Engler, that the most primitive Angiosperms to-day are those with unisexual flowers, and without perianth, e.g. Piperales, Pandanales, \&.c. This conclusion is criticised on the grounds that ( $\mathrm{I}$ ) the perianth must be assumed to arise de novo, and to be an organ sui generis; (2) such plants have a sharply defined and highly complicated inflorescence, which can hardly be regarded as primitive; (3) it has so far proved barren from a phylogenetic standpoint. On the contrary, they urge the acceptance of a strobiloid theory of the angiospermous fructification on the grounds that it is typically and primitively a diplosporangiate (hermaphrodite) cone with a vell-marked perianth, and one in which all the organs were originally numerous, spirally arranged, and hypogynous. It is pointed out that some of these primitive features are still retained among members of the Magnoliaceæ, Ranunculaceæ, Alismaceæ, \&c. From such a cone the authors would derive by reduction the apetalous, unisexual flowers. The flower is recognised as a special type of strobilus, to which the name Anthostrobilus is given, and of which two forms can be distinguished, the one gymnospermic, the other angiospermic. Both, however, are essentially of similar construction, especially as regards the peculiar juxtaposition of the micro- and mega-sporophylls, and the presence of a perianth. The view is expressed that the "motive force," which called the Angiosperms into existence, was a radical change in the method of pollination.

Physical Society, March 22.--Prof. J. Perry, F.R.S. president, in the chair.-Experimental mathematics: Mr. Pochin. An instrument for describing logarithmic spirals was exhibited, and it was shown how the principal properties of logarithms and of the equiangular spiral may be established as experimental results. $A$ spiral was described with an angle of $45^{\circ}$, and the positions of the radius vector, representing the first ten natural numbers, were drawn in. Cardboard sectors having been cut to fit the various angles, under the successive positions of the radius vector, it was shown that these sectors represented the logarithms of the numbers. Multiplication and division were illustrated by placing the sectors in juxtaposition, so that the angles were added or subtracted, the result being read off directly from the curve. A table of natural logarithms was also prepared from the spiral, by direct

NO. I 956. VOL. 75] 